\title{
RECYCLED PET ((POLY) ETHYLENE-TEREPHTHALATE) USED AS STRAPS FOR REBAR BINDING
}

\author{
UDC 666.97.055
}

\section{Miodrag Grbić, Milan Glišić, Radojko Obradović}

University of Belgrade, Faculty of Architecture, Belgrade, Serbia

\begin{abstract}
Recycling has an important role in modern production and in environment preservation. Introduction of recycled PET ((Poly) Ethylene-terephthalate) as straps for reinforcement bars in concrete construction elements can help these important issues. By using an experimental method it is shown that PET straps made with minimal investment, on site and with manual production can replace "annealed" wire as element for connection of reinforcement bars. An overview of some regulation and procedures is presented and used for eligibility assessment of the proposed straps made of recycled material. Also an overview of commonly used connections is given so it can be compared with the proposed ones.
\end{abstract}

Key words: rebar, binding, recycling, PET, on-site, handmade, metal free

\section{INTODUCTION}

Reinforcement rebar made of composites, whether they are made of PET, glass, aramid, carbon, or some other fibers in a polymer matrix, and which do not contain metal in itself, open the issue of mutual binding reinforcing bars. The smooth and ribbed steel reinforcement bars are bound "Annealed" wire. This is not a problem for a large percentage use of composite reinforcement but in certain percentage of implementation avoiding metal component is needed (for example Radar dome, etc.). Then the straps must be made of suitable material. There the recyclable PET comes in. It can be hand recycled and has even more useful characteristics.

Received March 25, 2016/ Accepted May 9, 2016

Corresponding author: Miodrag Grbić, Kraljevacka 50, Pančevo, Serbia

E-mail: grbic.miodrag@gmail.com 


\section{OVERVIEW OF REBAR BINDING MATERIALS}

\section{1. "Annealed" wire}

"Annealed" wire is produced from puled wire heated in furnace with a protective atmosphere (oxygen-free) at a temperature of 680-700 C. During the annealing changes the structure of the material of steel wire occur and it becomes soft and easy to bend. Is widely used in various processes of binding and packaging where it is not possible to use other materials (plastic, rope, etc.) [1].

The wire is sold at the kilogram and the thickness of the wire is in range of $1-3,1 \mathrm{~mm}$. The wire might be galvanized [1].



Fig. 1 "Annealed" wire [2]

\subsection{Straps made of polymers or other non metal materials}

Non metal straps are made from various polymers such as PVC Polyvinyl Chloride, PET (Polyethylene Terephthalate), HDPE (High density Polyethylene), PP (Polypropylene) or other material (Figure 2).
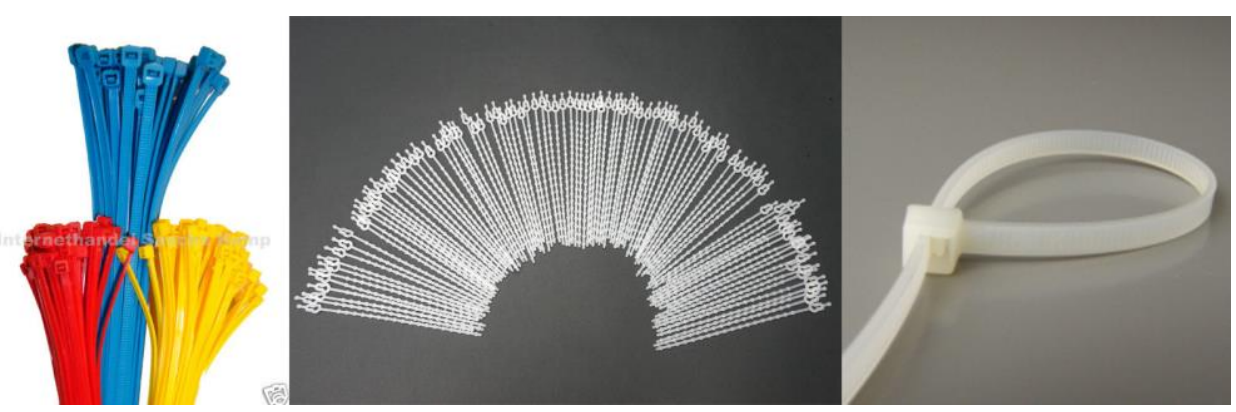

Fig. 2 Polymer based straps $[3,4,5]$ 
Most commonly used for epoxy-coated reinforcing bars, composite reinforcing bars, cases in which galvanization is a problem, etc. They are produced in processes such as extrusion or molding. A down side is the problem of ensuring a tight joint in the connection.

\section{OVERVIEW OF REBAR BINDING PROCESS AND PROCEDURES}

\subsection{Legislative and recommendations in USA}

In the USA a manual (CRSI Manual of Standard Practice) that is issued by Concrete Reinforcing Steel Institute gives instructions for good practice. The manual, in Chapter 10 , gives references and recommendations for rebar connecting process.

The CRSI book "Placing Reinforcing Bars" page 10-27 to 10-32 gives examples of different types of ties and why and when they are used, with other information concerning ties and wire.

For example, for most construction in commercial work, it is usual to tie a $50 \%$ of rebar intersections, and $50 \%$ tie indicates that every other cross must be tied. The percentage can go to more than $100 \%$. A $100 \%$ tie would indicate tying every cross section, and in some instances, when using large bar, it may call for even $200 \%$ tie which is two wires at each intersection. That means that making $200 \%$ tie the wires must run opposite each other.

"The proper tying of bars is essential in order to maintain bar positions during work done by other trades and during concrete placing. It is not necessary to tie bars at every intersection. Tying adds nothing to the strength of the finished structure. In most cases, a tie at every $4^{\text {th }}$ or $5^{\text {th }}$ intersection is all that is necessary. Ends of finished ties should be kept clear of the concrete surface. When tying bars in slabs that are being assembled in place, the spacing of ties should be governed by the bar sizes. Usually snap ties are used. Wall bars that are assembled in place should be tied sufficiently to prevent shifting as concrete is being placed. The snap tie or wrap and snap tie is generally used, but in most cases the snap tie is adequate. For preassembled mats, a sufficient number of bar intersections should be tied to make the mats rigid enough for handling. When snap ties are used, every bar intersection around the perimeter and alternate intersections within the interior of the mat should be tied" [6].

Serbian valid regulations $\mathrm{PBAB}$ ' 87 does not take in consideration types, number of ties, necessary percentage of ties to number of rebar intersections, etc.

It is only mentioned in paragraph 256 . The exact formulation is:

"During installation of rebar it is very important to secure designed position and assure there are no possibilities of displacement of rebar during embedding of concrete. That means rebar must be connected with thin wire or spot welding, or application of some other kind of mechanical means, and it is also essential to apply necessary number of restrains and pads of the appropriate type" [7].

This formulation should not be considered as any kind of adequate instruction for rebar installation and temporary connections. 


\subsection{Types of ties for installation of reinforcement bars}

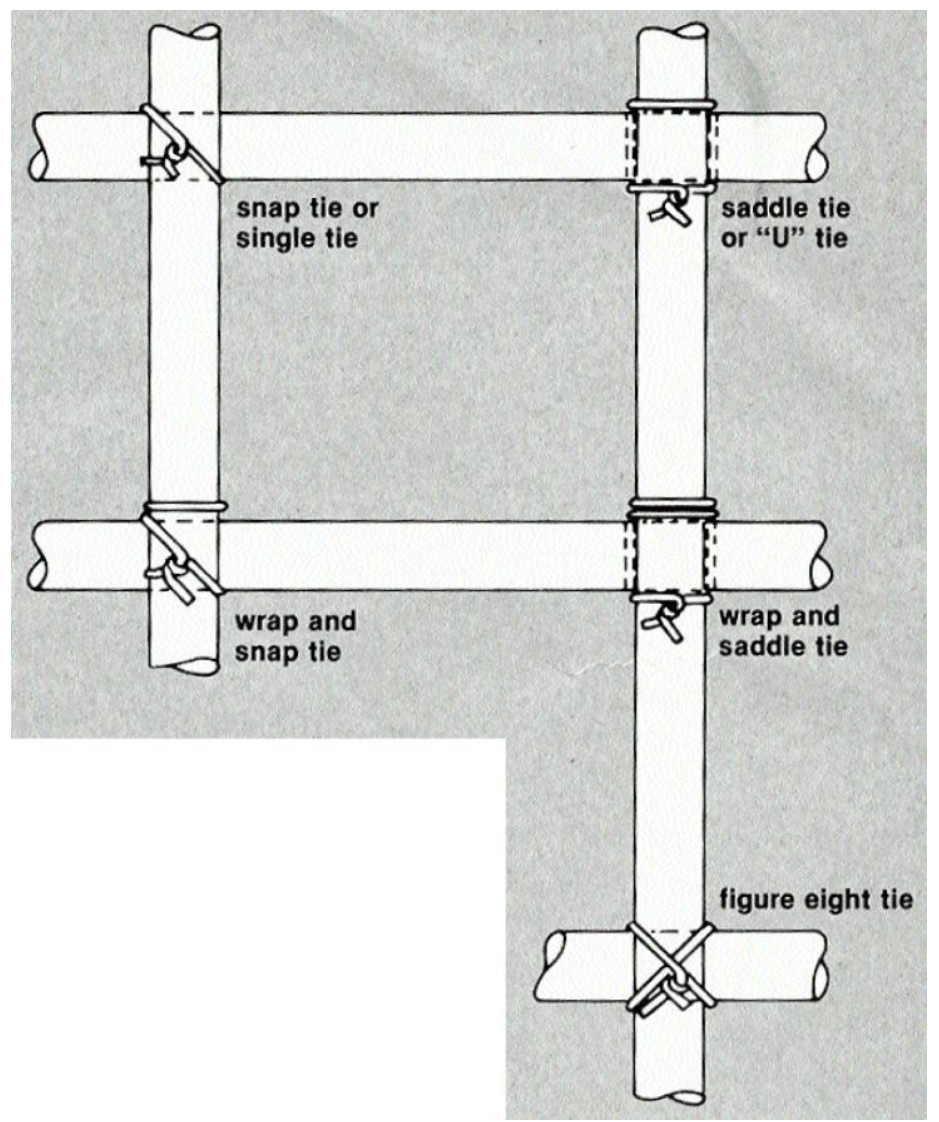

Fig. 3 Some of different types of ties may be needed for floors, walls, heavy mats, columns or reassembled cages. Bars must be held securely in position so that they do not shift while work is being done by other trades or during concrete placing [6].

"There are various types of ties used when securing reinforcing bars. Much of the tying is done on flat, horizontal formwork such as floor slabs, and many backaches can be saved if one learns to bend and tie stiff-legged instead of squatting. Several of the most common types of ties are described on these pages and illustrated in Figure 3." [6]

"A snap or single tie is normally used in flat horizontal work to secure the reinforcing bars in position against displacement due to work done by other trades and by concrete placing. This is a very simple tie; it is wrapped once around the two crossing bars in a diagonal manner with the two wire ends on top. The wires are then twisted together with a pair of pliers until they are tight against the bars. The wire is cut with pliers and the ends flattened, to prevent them from snagging clothing and from protruding through the concrete surfaces. The snap or single tie may be made stronger by and around the first bar where they are twisted as shown." [6] 
"The wrap and saddle tie is similar to the saddle tie except that the wire is wrapped 1,5 times around the first bar, then completed as described for the saddle tie. This type can be used to secure heavy mats that are lifted by crane and for securing column ties to vertical bars where there is a considerable strain on the ties." [6]

"A figure eight tie is occasionally used in walls instead of the wrap and snap tie." [6]

\subsection{Observations about connecting and installation of reinforcing bars in regular procedures}

An experienced Rod Buster using preformed "annealed" wires and a pigtail could make a dozen ties in the time you could set one plastic tie and when done the wire tie would be much tighter than you can pull the plastic tie. The time required to make each joint extra tight is substantial factor that decreases the use of plastic straps in this process, and even then it is doubtful that you would gain any tensile strength in the tie.

But ties contribute with very little strength to the final assembly of reinforced concrete element. If additional strength is required, the bars are welded together and that is the case that is not being considered now.

When properly tied with wire the rebar cage should be strong enough to be tied on the side, lifted and set into place by a crane without any loss of structural integrity. Also it should withstand pressure of concrete during embedding. And once the concrete hardens the ties serve no purpose as the rebar is totally encapsulated in the concrete.

\section{USE OF RECYCLED PET (Polyethylene TeREPHTHALATE)}

\subsection{Reasons for introducing on site recycled PET}

There was already a mention of epoxy-coated reinforcing bars, and "CRSI Manual of Standard Practice" suggests that these bars shall be tied with plastic-coated or epoxycoated steel wire, or other acceptable material.

Polyethylene Terephthalate or most commonly known as PET is a material that is adequate for that kind of use. It has a tensile strength and is elastic, and at the same time has properties that allow it not to damage reinforcing bars and their coating. PET does not conduct electricity so galvanization is not possible true connections. If it is used to make ties for polymer based composite reinforcement, metal presence in construction elements can be avoided.

Straps can be made from used PET bottles on construction site. Advantage is easy recycling with no use of energy, with simple tools and just manual work.

Making tools for PET strap production (Figure 4). 


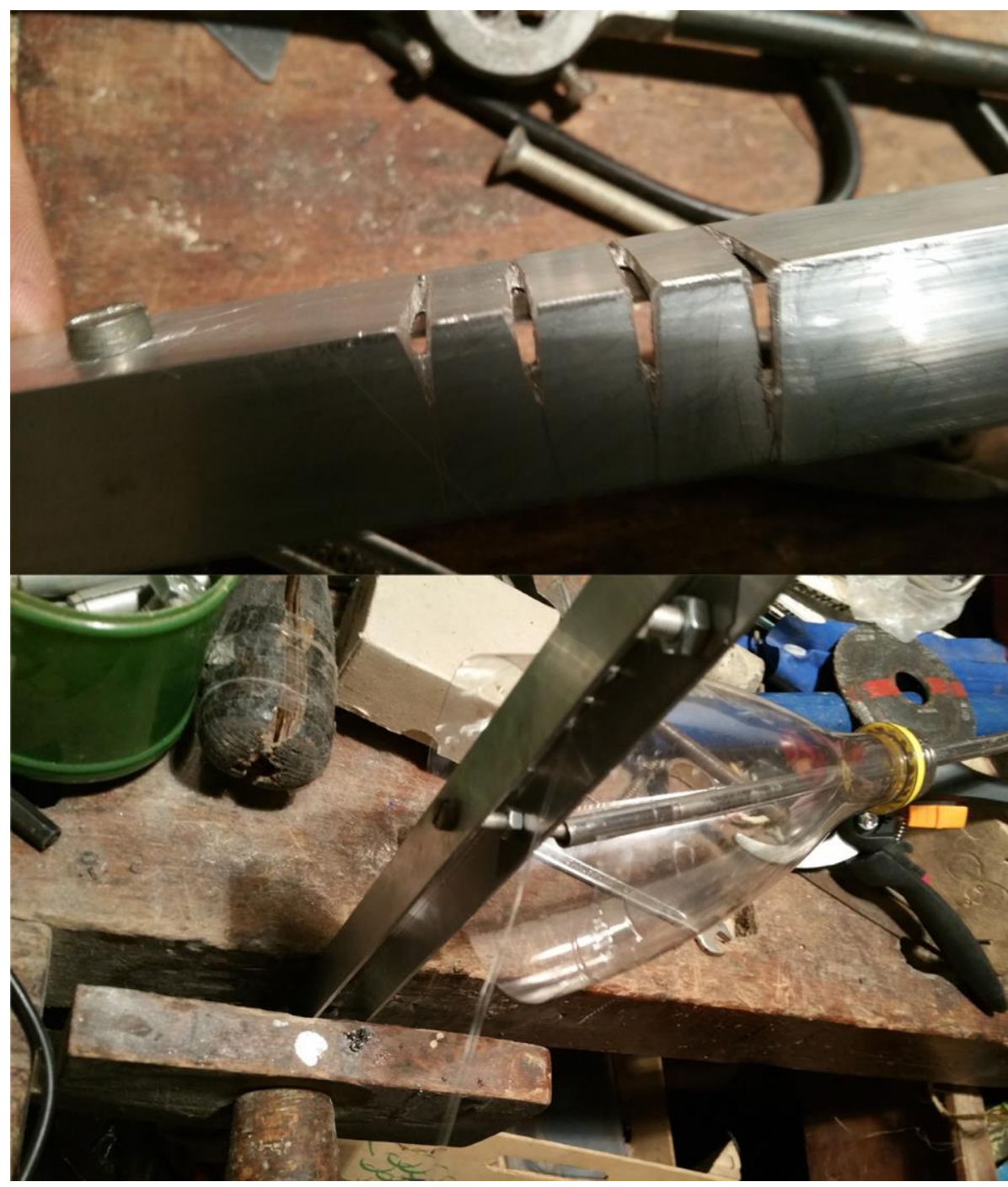

Fig. 4 Tools for PET strap and production of PET straps

There is one more advantage that concerns properties of material and its thermoplastic capabilities. These PET straps shrink as they are subjected to heat. In this way we can insure a tight connection between reinforcing bars. And the exposure to temperature is short so it does not influence rebar due to small mass of strap used for connection in comparison to rebar.

PET strap reduction in length in reaction to heat source (Figure 5). 

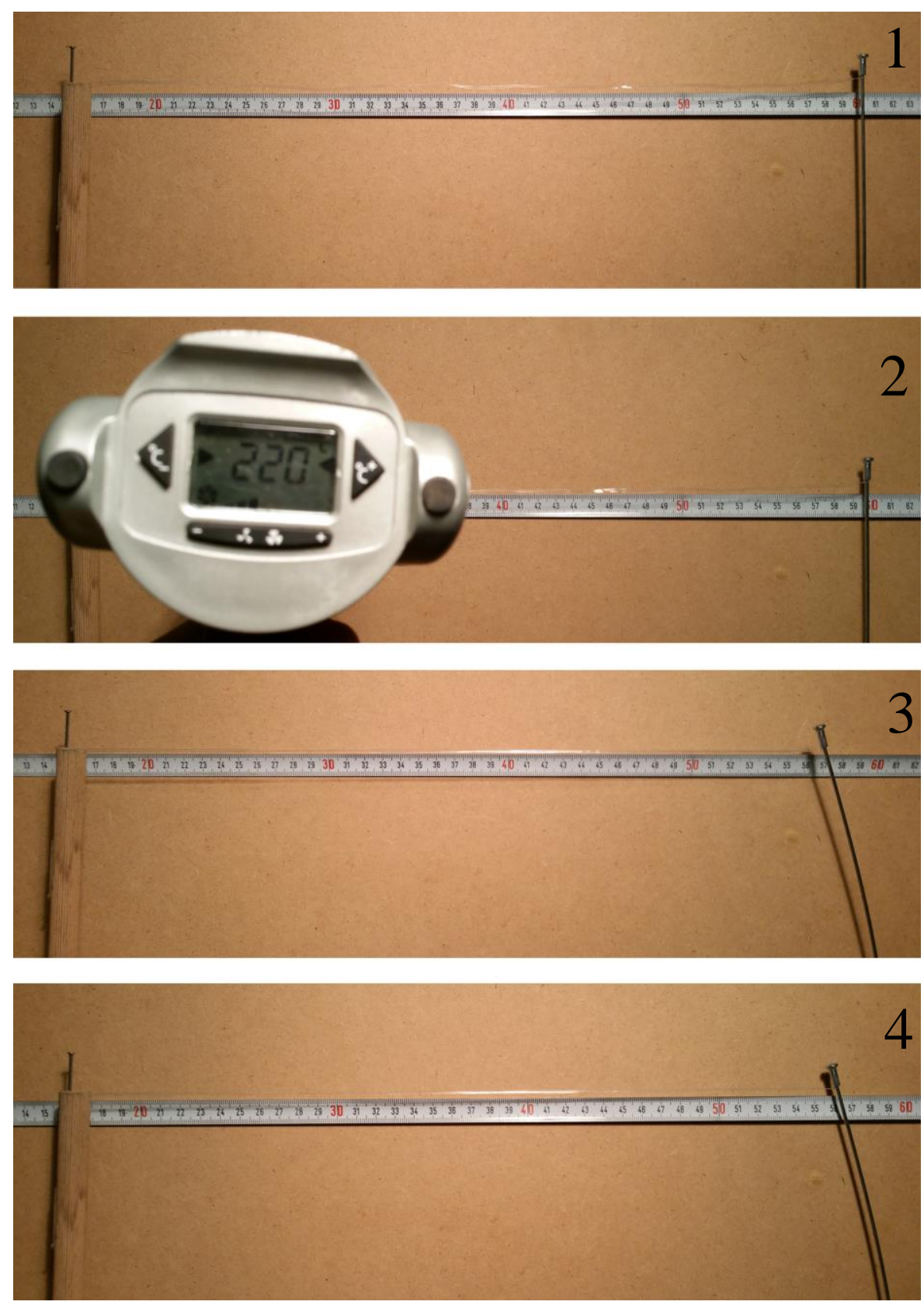

Fig. 5 PET strap reduction in length 
Figure 5 shows PET strap reduction in length in reaction to heat source in 4 sequences. The strap is stretched in between unmovable and movable support with no strain on start of process of heating. Sequence 1 is $43,6 \mathrm{~cm}$ long PET strap pulled out from PET bottle in its original state. Sequence 2 shows operating temperature of heat source. Sequence 3 is mid state with $3 \mathrm{~cm}$ reduction of length after 30 second of gradually subjecting to temperature. And sequence 4 is total reduction of length after 1 minute of heating process with reduction of $4 \mathrm{~cm}$ in total.

It can be noticed that total reduction is about 9,2\% of start length of PET strap. This reduction is significant enough to be sufficient for ensuring a tight connection of reinforcement bars.

\subsection{Test performance of PET straps}

The strap is produced from used PET bottles and by manual work with simple handmade tools. Bottle bottom is to be cut off and then the bottle new formed edge is inserted in the tool. By simple puling we can get strap that is in fact one long line of pet material. That line can differ in size. The sizes are predefined by the tool that is used. The width of line is in range of 1 milimetar to several centimeters (Figure 4).

Wider straps then 3 or $4 \mathrm{~mm}$ are bulky for use as tie for rebar.

When the straps are in long lines and spooled they are ready to be used. The rebar that is to be embedded in concrete element is prepared to be tied. The line is cut to smaller parts that are about $15-20 \mathrm{~cm}$ in length. The strap is than is wound on the intersection or crossing of rebar and the ends are bound. After completing all the necessary connections the straps are to be heated. Heating can be done by heating fan or by flames of some kind (gas, coal, charcoal). It sets on the shortening of straps and insures tight connection. (Figure 7).
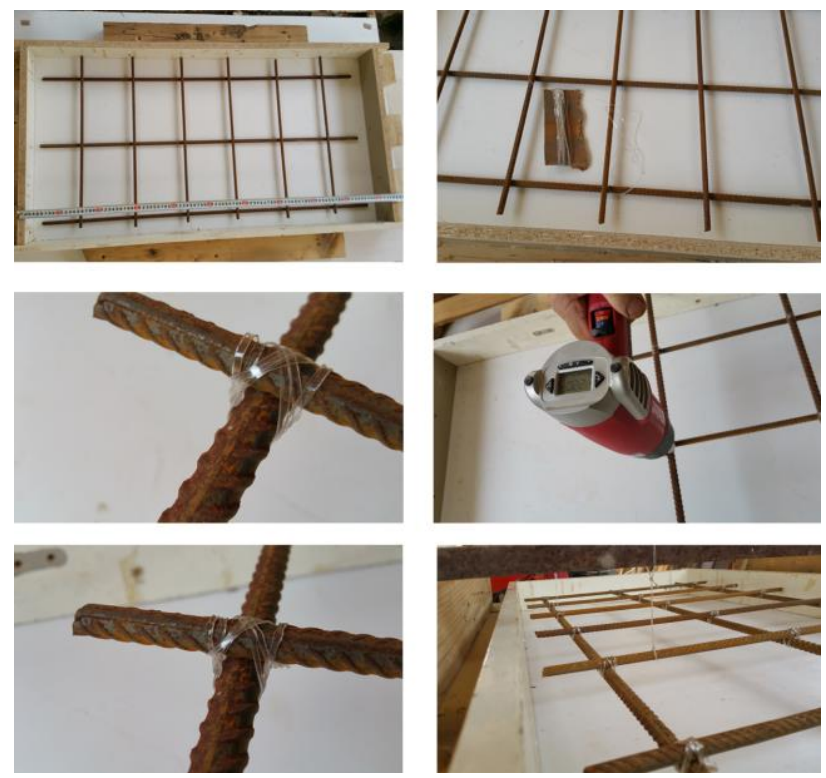

Fig. 7 Setting rebar ties 
As rebar is placed for embedding the concrete made on site is poured on top. Concrete in this test was additionally vibrated for better placement. The construction element is than left for concrete to mature (Figure 8). For this test the element was left for 8 days and concrete should have matured to at least $70 \%$ of its strength. The strength of concrete is not a critical factor so the time consuming process of waiting 28 days for $100 \%$ in strength is omitted.

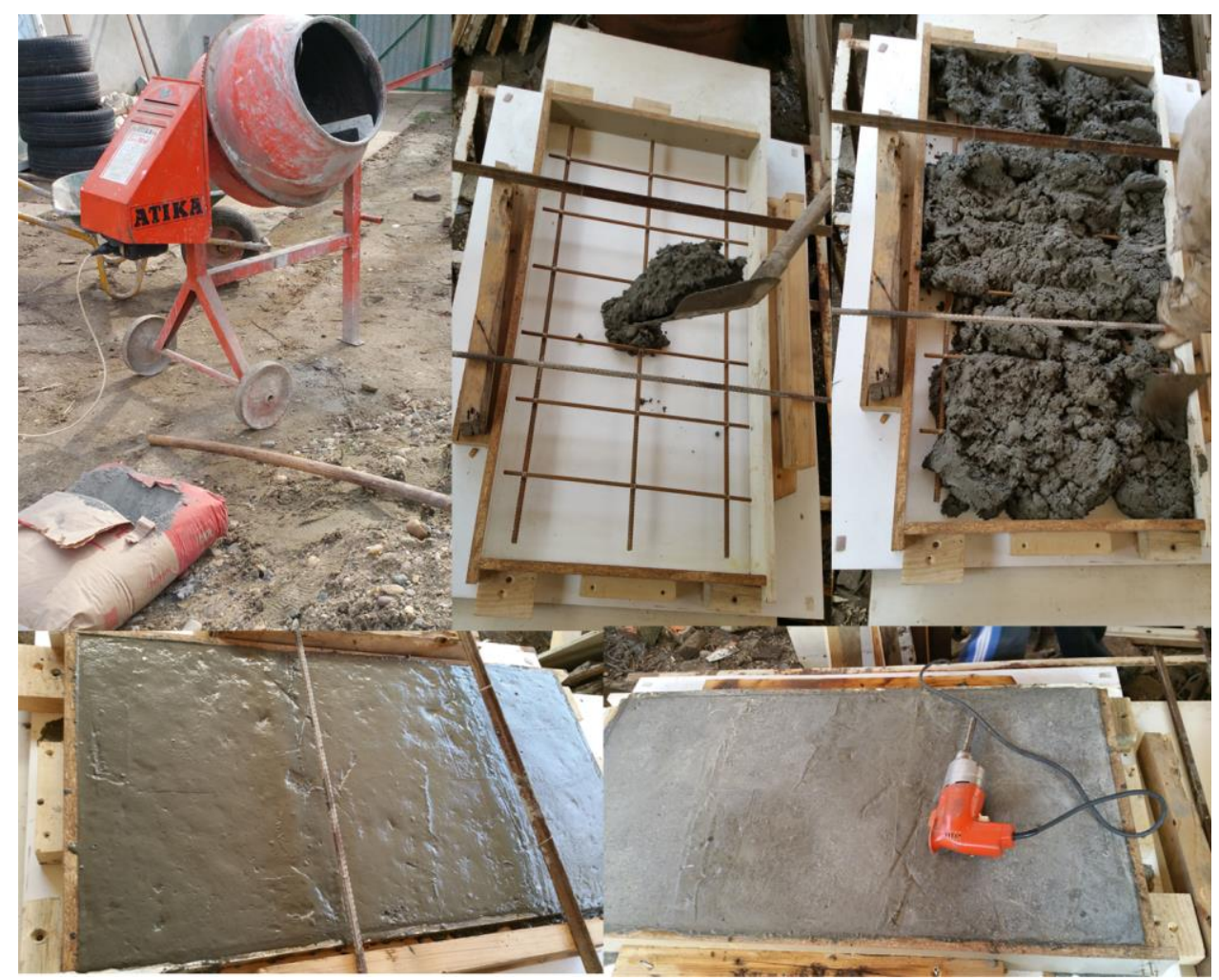

Fig. 8 Embedding concrete

The concrete influence is critical in terms of the forces that act on reinforcement bars and connection of that reinforcement during installation process, and to some extents is interesting to see impact when the concrete is demolished. The demolition is performed to verify that the reinforcement bars did not experience deflection from the predefined position. (Figure 9) 


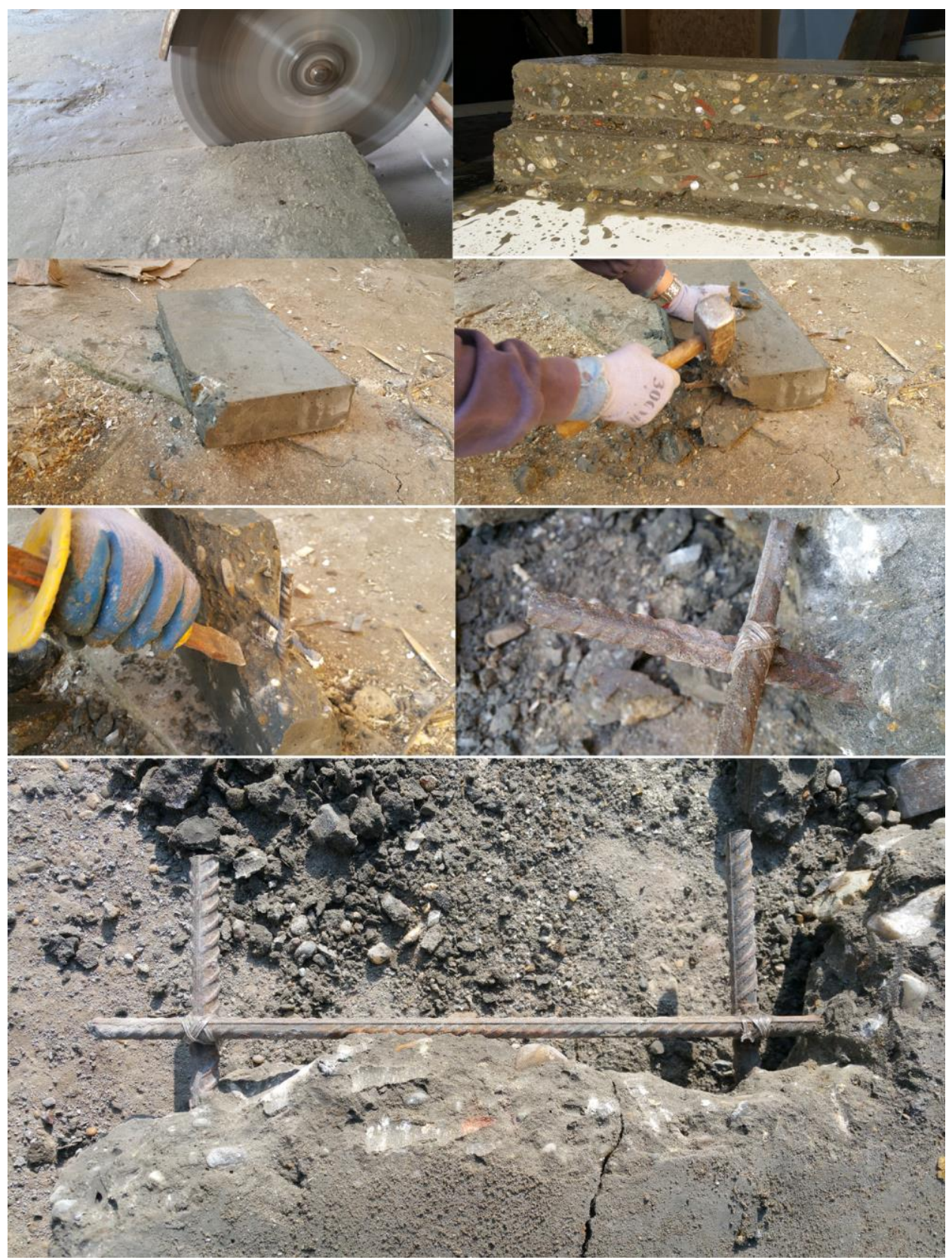

Fig. 9 The demolition and visual detection

Demolition is also carried out on site and by using simple procedures. The cutting of concrete element is preformed to detect position of rebar and also chiseling to open intersection of rebar and check condition of PET strap ties (Figure 9). 


\section{CONCLUSION}

After insight in material, recommended procedures and practice, and also on site experiment it can be concluded that PET straps can be used for rebar ties during installation. It is evident that straps give satisfying results and are suitable for use in rebar binding. There are still some opened issues that are to be considered, like increasing a speed of installation, etc. Nevertheless this type of connection can be useful for ties when epoxy-coated reinforcement bars are to be installed because it does not damage the coating and the rebar stays protected. If there is a need for avoiding use of metal in concrete elements the use of composite rebar without metal can be also complemented with recycled PET straps. The property of thermoplastic deformation that is manifested by decrease in length is a characteristic that gives it an edge by giving the straps an ability to put tension in the tie connections of rebar. And as the recycling is becoming ever more important factor we can contribute with this procedure and manufacture straps that are produced by using worker power with minimal consumption of energy. It is also important to underline the need for more accurate defining of necessary procedures by the Legislative and Regulations.

\section{REFERENCES}

1. http://www.mas-promet.co.rs/product_details.php?idp=11384\&r=3161\&inkl=\&pro=Paljena\%20\%C5\%BEica

2. http://swuk.net/wp-content/uploads/2014/11/Reinforcement-mesh-tying-wire.jpg

3. http://www.splast.si/images/vezice/vezice02-v.jpg

4. http://www.splast.si/images/vezice/vezice03-v.jpg

5. http://www.artmatch.net/sites/default/files/styles/taxonomy-term/public/term_385_0.jpg?itok=bzeyfPIQ

6. Concrete Reinforcing Steel Institute, " Placing Reinforcing Bars", CRSI, 933 North Plum Grove Road, Schaumburg, Illinois 60195, pp. 10-27 to 10-32, August 2011

7. PBAB '87, Građevinska knjiga, pp. 736, Belgrade, 1995

\section{UPOTREBA RECIKLIRANOG PET-A ((POLI) ETILEN-TEREFTALAT) ZA VEZIVANJE ARMATURE}

Reciklaža zauzima sve važniju ulogu u modernoj proizvodnji $i$ očuvanju životne sredine. Uvođenje recikliranog PET-a ((Poli) Etilen-tereftalat) kao veze za armaturne šipke u betonskim konstruktivnim elementima može doprineti ovim važnim ciljevima. Korišćenjem eksperimentalne metode pokazano je da ovakve veze načinjene od recikliranog PET-a, uz minimalne investicije, napravljene na licu mesta i ručnom izradom mogu zameniti "paljenu”žicu kao element kojim se ostvaruje konekcija između armaturnih šipki. Dat je i kratak pregled nekih propisa i procedura koje su korišćene za procenu predloženih veza od navedenog recikliranog materijala. Takođe je dat i pregled najčešće korićenih veza kako bi moglo da se napravi poređenje sa predloženim rešenjem.

Ključne reči: armatura, vezivanje, reciklaža, PET, na gradilištu, ručna izrada, bez metala 